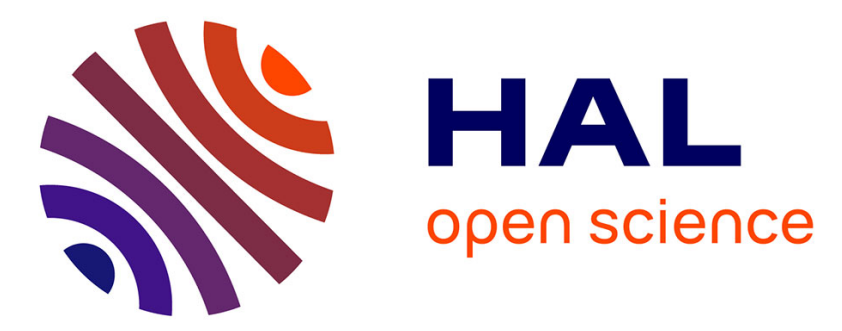

\title{
Drying Kinetics Comparison of Methylcellulose Gel Versus Mango Fruit in Forced Convective Drying With and Without Electrohydrodynamic Enhancement
} Erik Bardy, Sabrine Manai, Michel Havet, Olivier Rouaud

\section{- To cite this version:}

Erik Bardy, Sabrine Manai, Michel Havet, Olivier Rouaud. Drying Kinetics Comparison of Methylcellulose Gel Versus Mango Fruit in Forced Convective Drying With and Without Electrohydrodynamic Enhancement. Journal of Heat Transfer, 2016, 138 (8), pp.084504. 10.1115/1.4033390 . hal-01798548

\author{
HAL Id: hal-01798548 \\ https://hal.science/hal-01798548
}

Submitted on 23 Oct 2018

HAL is a multi-disciplinary open access archive for the deposit and dissemination of scientific research documents, whether they are published or not. The documents may come from teaching and research institutions in France or abroad, or from public or private research centers.
L'archive ouverte pluridisciplinaire HAL, est destinée au dépôt et à la diffusion de documents scientifiques de niveau recherche, publiés ou non, émanant des établissements d'enseignement et de recherche français ou étrangers, des laboratoires publics ou privés. 


\title{
DRYING KINETICS COMPARISON OF METHYLCELLULOSE GEL VS. MANGO FRUIT IN FORCED CONVECTIVE DRYING WITH AND WITHOUT ELECTROHYDRODYNAMIC ENHANCEMENT
}

\author{
Erik Bardy ${ }^{1}$ \\ Department of Mechanical Engineering \\ Grove City College \\ Grove City, PA 16127, USA \\ erbardy@gcc.edu \\ Sabrine Manai \\ Laboratoire de Génie des Procédés Environnement et Agroalimentaires \\ ONIRIS, Nantes, France \\ sabrine.manai@oniris-nantes.fr \\ Michel Havet \\ Laboratoire de Génie des Procédés Environnement et Agroalimentaires \\ ONIRIS, Nantes, France \\ michel.havet@oniris-nantes.fr

\section{Olivier Rouaud} \\ Laboratoire de Génie des Procédés Environnement et Agroalimentaires \\ ONIRIS, Nantes, France \\ olivier.rouaud@oniris-nantes.fr
}

\begin{abstract}
Electrohydrodynamic convective drying (EHD drying) is a novel drying method used to enhance forced convection drying (FC drying) by using a wire-electrode to create an electrostatic field. In a previous study, the efficiency of EHD drying (using three different wire-electrode configurations) was compared to classical FC drying by measuring the drying rate of methylcellulose gel. Efficiency was quantified in terms of exergy (transient exergetic efficiency) through the use of a proposed model. In that previous study, it was stated that methylcellulose gel can be used to simulate a food product, and can be controlled to a predetermined moisture content. The purpose of this current work was to compare how methylcellulose gel compares to a real food product (mango fruit) in terms of drying kinetics for both EHD and FC drying. Drying kinetics were quantified in terms of a per unit area measurement of the exergetic efficiency, exergy supplied and used, drying rate, and total drying time to reach a moisture content of 50\%. Initial results show that for both EHD and FC drying, methylcellulose gel and mango fruit both exhibit similar drying kinetics.
\end{abstract}

\footnotetext{
${ }^{1}$ Corresponding author information can be added as a footnote.
} 


\section{INTRODUCTION}

Drying is an energy intensive unit operation encountered in many industrial sectors. Drying is mainly used to lower the water content of food with high moisture content (>80\%) [1]. Drying offers many benefits including: extended shelf-life, reduced packaging, storage, handling and transportation costs along with out-of-season availability. Several developed countries have reported that between $12-20 \%$ of their national industrial energy consumption is due to thermal dehydration operations [2]. Dehydration is exceptionally energy intensive [3], and thereby inefficient [4], especially in forced convective drying (FC drying) due to high airflow velocities. One innovative way to reduce energy consumption and increase efficiency is through ElectroHydroDynamic drying (EHD drying). EHD drying uses a wire-electrode(s) suspended above the food product in the main air stream to generate a corona discharge. This causes an ionic air stream that disrupts the primary air flow and alters the boundary layer above the food product. This results is an intensification of convective heat transfer and mass transfer between the air and the drying product for low primary airflow velocities [5]-[8].

In a study by Bardy et al. [5], the efficiency (quantified in terms of exergetic efficiency) and drying rate of FC verses EHD drying were compared for various wire-electrode configurations using methylcellulose gel as the test specimen. It was found that EHD drying could yield the same drying rates as FC drying with $80-85 \%$ less airflow velocity, which resulted in a significant increase in exergetic efficiency. In that particular study, Bardy et al. [1] chose methylcellulose gel as a test specimen since it can be controlled to a predetermined moisture content. In addition, it was stated that methylcellulose gel can be used to simulate food products. The purpose of this current work was to determine how methylcellulose gel compares to a real food product (mango fruit) in terms of drying kinetics for both EHD and FC drying. In the context of this study, drying kinetics was quantified in terms of drying rate, along with transient and overall exergetic efficiency quantified using a model presented in Bardy et al. [5]. Bardy et al. [5] defined transient and overall exergetic efficiency as the ratio of exergy used for drying over the total exergy supplied (i.e. exergy is supplied by air for FC drying, and by air and the EHD effect for EHD drying).

\section{METHODS}

The experimental set-up for this study was similar to Bardy et al. with some minor modifications [5].

\section{Experimental Set-up}

The experimental set-up consisted of a rectangular air flow channel $(15 \mathrm{~cm} \times 19 \mathrm{~cm}$ x $200 \mathrm{~cm})$ used to dry humid test specimens (representing food products) by means of FC drying with and without an electrostatic field (EHD drying). The channel was connected to an air handling unit (ML180, Munters, France) used to control the psychrometric conditions and the flow rate of the air entering the channel. A wire-electrode suspended above the test specimen was connected to a high voltage generator (GLHT2260R2, Sefelec, France) in order to produce an electrostatic field. The air flow channel was placed on a table top which had a square hole cut to fit a tray that held the test specimen. The tray was constructed of a copper bottom with polystyrene borders and held in place a $15 \times 15 \times 0.5 \mathrm{~cm}$ test specimen exposing the upper surface. The copper bottom of the tray was grounded to allow current to flow from the wire-electrode through the test sample. The tray was placed on a weight scale (Radwag, PS600, Germany) to measure the change in mass of the test specimen due to moisture loss during the drying process. The weight scale was covered with aluminum foil to create a Faraday cage. The surface of the test specimen was aligned to be flush with the bottom surface of the air flow channel.

The air entering the flow channel was psychrometrically controlled at a temperature and relative humidity of $35^{\circ} \mathrm{C}$ and $20 \%$, respectively. A data acquisition system (Logidat, AOIP, France) was used to measure the entering air temperature and relative humidity, ambient air temperature as well as the applied voltage and current (between the wire electrode and the test specimen tray) in increments of 5 minutes during the course of drying. A separate data acquisition system software (SartoConnect, V. 3.5.2, Germany) was used to set the weight scale to measure the mass of the test specimen at the same time interval.

A total of three different wire-electrode configurations were tested for EHD drying. Each configuration had an airflow velocity of $0.3 \mathrm{~m} / \mathrm{s}$. Two experiments were run for each configuration (total of 6 experimental runs). One FC drying experiment was run for airflow velocities of 0.3 and $3.0 \mathrm{~m} / \mathrm{s}$. Airflow for both EHD and FC drying experiments were measured using an air flow meter. Table 1 shows the details (configuration) of each experimental case for both EHD and FC drying. Each experimental case is referenced from this point on according to the notation in Table 1. 


\section{Test Specimen Preparation \\ Mango}

Fresh mangoes (kent variety) of homogeneous color and size were selected and bought at a local supermarket. The fruit was immersed in sodium hypochlorite at $100 \mathrm{ppm}$ for $10 \mathrm{~min}$ and then washed with tap water. Then, the mango was cut into $5 \mathrm{~mm}$ thick slices with an electric slicer (model SOFRACA, Morangis, France). Several slices were then placed on the sample tray in an attempt to cover as much the surface of the tray as possible. The tray was then covered by a plastic film. The tray was then placed at the exit of the flow channel for the sample to equilibrate with the temperature of the flowing air. The moisture content of the mango samples ranged from $83-86 \%$ (water mass to total mass).

\section{Methylcellulose Gel}

Test specimens were prepared by mixing the methylcellulose gel powder with water (Tylose, ShinEtsu, H100000, Germany). A plastic film was then placed on the mold and the liquid mixture was poured into the specimen tray until the cavity was filled. The tray was left uncovered until the surface of the liquid mixture formed a film. It was then covered with plastic film and left to cure. The moisture was fixed at $83 \%$ to most closely resemble the mango fruit.

\section{Testing Protocol}

Before each experimental run, the test specimen was weighed followed by being wrapped again in plastic film. The airflow velocity was adjusted to the desired value (i.e. $0.3 \mathrm{~m} / \mathrm{s}$ for EHD drying, 0.3 and $3.0 \mathrm{~m} / \mathrm{s}$ for FC drying) and verified with the airflow meter. The data acquisition system was then configured to measure air properties (inlet air temperature and relative humidity, and ambient air temperature) and EHD voltage and current in increments of 5 minutes. The proprietary weight scale software was also configured to record the test specimen weight every 5 minutes as well. After the data acquisition systems were configured (but not yet launched) the glass cover of the airflow channel was removed and the test specimen was unwrapped and placed on the specimen tray. Care was taken to bend the test specimen around the electrodes (so as not to touch the electrodes) while placing it in the tray. The glass cover to the airflow channel was then placed back on the airflow channel. If an EHD drying experiment was run the voltage would then be applied after placing the glass cover on the flow channel. Closely following the placement of the glass cover (or application of the voltage) both data acquisitions were launched as close to the same time as possible. The experiment was left to run until the moisture content reached $50 \%$.

\section{RESULTS AND DISCUSSION}

Table 2 shows the initial test specimen properties, the total drying time, the exergy supplied by EHD and air, as well as the exergy used for drying, and exergetic efficiency for each FC and EHD drying case for both the methylcellulose gel and mango (each value is shown as an average of the two experimental runs per case with standard deviation).. The indicated drying times and exergetic values equate to when the moisture content of the test specimen reached 50\%. Each value indicated in Table 2 was averaged over the two experimental runs for each case. In addition, since the methylcellulose gel and mango test specimens have different initial surface areas, the exergy used for drying and the exergetic efficiency were normalized to the initial surface area of the test specimen.

As showed in Table 2, the methylcellulose gel and mango had similar drying times for all FC and EHD cases with the exception of EHD drying case 1 (one wire-electrode arranged perpendicular to airflow). The drying time of mango was $8.50 \pm 1.65$ hours compared to $16.33 \pm 0.94$ hours for methylcellulose gel. Both test specimens had approximately the same used exergy and initial moisture content. The faster drying time of the mango resulted in an overall exergetic efficiency of approximately twice that of methylcellulose gel. In addition, there is no statistically significant difference between the drying time and overall exergetic efficiency means between mango and methylcellulose gel at the alpha $=0.05$ level of significance $(p=0.074$ and $\mathrm{p}=0.100$, respectively) among all the drying experiments.

Figures 1 and 2 show the drying rate and transient exergetic efficiency over time (normalized to initial surface area of test specimen, $\mathrm{cm}^{2}$ ) of methylcellulose gel compared to mango for all the FC and EHD drying cases, respectively. Both the drying rate and transient exergetic efficiency has been normalized to the initial surface area of the test specimen (indicated in Table 2). As can be seen, both the drying rate and 
transient exergetic efficiency of the methylcellulose gel followed very closely to that of mango for FC drying case $2(3.0 \mathrm{~m} / \mathrm{s})$ and for EHD drying cases 2 and 3. For FC drying case $1(0.3 \mathrm{~m} / \mathrm{s})$, the initial drying rate of mango started at a higher rate $\left(4 \mathrm{~g} / \mathrm{hr} / \mathrm{cm}^{2}\right)$ than the methylcellulose gel $\left(2.5 \mathrm{~g} / \mathrm{hr} / \mathrm{cm}^{2}\right)$. In addition, the drying rate over time of the mango decreased faster than the methylcellulose gel for FC drying case $1(0.3 \mathrm{~m} / \mathrm{s})$. This attributed to the faster drying time for mango as compared to methylcellulose gel (Table 2). The difference in drying behaviour could be due to the low airflow velocity. According to Figure 2, the transient exergetic efficiency followed the same trend as the drying rate since the exergy supplied by the air was approximately the same. For EHD drying case 1, the initial drying rate of mango ( 9 $\left.\mathrm{g} / \mathrm{hr} / \mathrm{cm}^{2}\right)$ was greater than that of methylcellulose gel $\left(6 \mathrm{~g} / \mathrm{hr} / \mathrm{cm}^{2}\right)$. The drying rate of mango decreased sharply for the first 3 hours. The drying rate then slowly decreased for the remainder of the experiment. The drying rate of the methylcellulose gel on the other hand decreased sharply for the first 5 hours of drying (for EHD drying case 1) and then slowly levelled off for the reminder of the experiment. The transient exergetic efficiency followed the same effect (Figure 2). These drying kinetics could be modelled by semi-theroretical correlation in a similar manner as was done by Taghian-Dinani et al. [9].

\section{CONCLUSIONS}

This study focused on comparing the drying kinetics of methylcellulose gel compared to mango for FC and EHD drying. Drying kinetics was quantified in terms of drying rate, along with transient and overall exergetic efficiency quantified using a model presented in Bardy et al. [5] (normalized to initial surface area of test specimen, $\mathrm{cm}^{2}$ ). Results show similar drying rates and exergetic efficiencies per test specimen area for both mango and methylcellulose gel for FC and EHD drying. Some differences in drying rate and exergetic efficiency did occur for low airflow velocities in FC drying, as well as for EHD drying with an electrode arranged perpendicular to airflow. Additional study will need to be made to investigate this further.

\section{ACKNOWLEDGMENT}

This research was supported by the Pays de Loire program (PERLE2). These results were also presented at the First Pacific Rim Thermal Engineering Conference (PRTEC) [10].

\section{REFERENCES}

[1] J. Moses, T. Norton, K. Alagusundaram, and B. Tiwari, "Novel Drying Techniques for the Food Industry," Food Eng. Rev., vol. 6, pp. 43-55, 2014.

[2] A. Mujumdar, "Perspectives on International Drying Symposium Series - Past, Present and Future Prospects," in Proceedings of the 19th International Drying Symposium, 2014.

[3] S. Ould Ahmedou and M. Havet, "Effect of Process Parameters on the EHD Airflow," J. Electrostat., vol. 67, no. 2-3, pp. 222-227, 2009.

[4] J. Wang, Y. W. Wang, J. W. Wang, and X. L. He, "Drying Characteristics and Drying Quality of Kidney Beans Using a Two-Stage Microwave Process," J. Food Process Eng., vol. 31, no. 3, pp. 413-430, 2008.

[5] E. Bardy, M. Hamdi, M. Havet, and O. Rouaud, "Transient exergetic efficiency and moisture loss analysis of forced convection drying with and without electrohydrodynamic enhancement," Energy, vol. 89, pp. 519-527, 2015.

[6] Y. Bai, Y. Hu, and X. Li, "Influence of Operating Parameters on Energy Consumption of Electrohydrodynamic Drying," Int. J. Appl. Electromagn. Mech., vol. 35, pp. 57-65, 2011.

[7] F. D. Li, L. T. Li, F. Sun, and E. Tatsumi, "Effect of Electrohydrodynamic (EHD) Technique on Drying Process and Appearance of Okara Cake," J. Food Eng., vol. 77, no. 285-280, 2006.

[8] S. Ould Ahmedou, O. Rouaud, and M. Havet, "Assessment of the Electrohydrodynamic Drying Process," Food Bioprocess Technol., vol. 2, pp. 240-247, 2009.

[9] S. Taghian Dinani, N. Hamdami, M. Shahedi, and M. Havet, "Mathematical modeling of hot air/electrohydrodynamic (EHD) drying kinetics of mushroom slices," Energy Convers. Manag., 
ASME Journal of Heat Transfer

vol. 86, pp. 70-80, 2014.

[10] E. Bardy, S. Manai, M. Havet, and O. Rouaud, "Drying Kinetics Comparison of Methylcellulose Gel Vs. Mago Fruit in Forced Convective Drying with and without Electrohydrodynamic Enhancement," in The First Pacfic Rim Thermal Engineering Conference, 2016. 


\section{Figure Captions List}

Fig. 1 Drying rate (normalized to initial surface area of test specimen, $\mathrm{cm}^{2}$ ) over time of methylcellulose gel verses mango for all FC and EDH drying experimental cases.

Fig. 2 Transient Exergetic Efficiency (normalized to initial surface area of test specimen, $\mathrm{cm}^{2}$ ) over time of methylcellulose gel verses mango for all FC and EDH drying experimental cases.

\section{Table Caption List}

Table $1 \quad$ Placement of wire-electrode for EHD drying experiments.

Table 2 Initial test specimen properties and overall drying time, exergy used for drying and exergetic efficiency for each EHD and FC drying case for both mango and methylcellulose gel. 

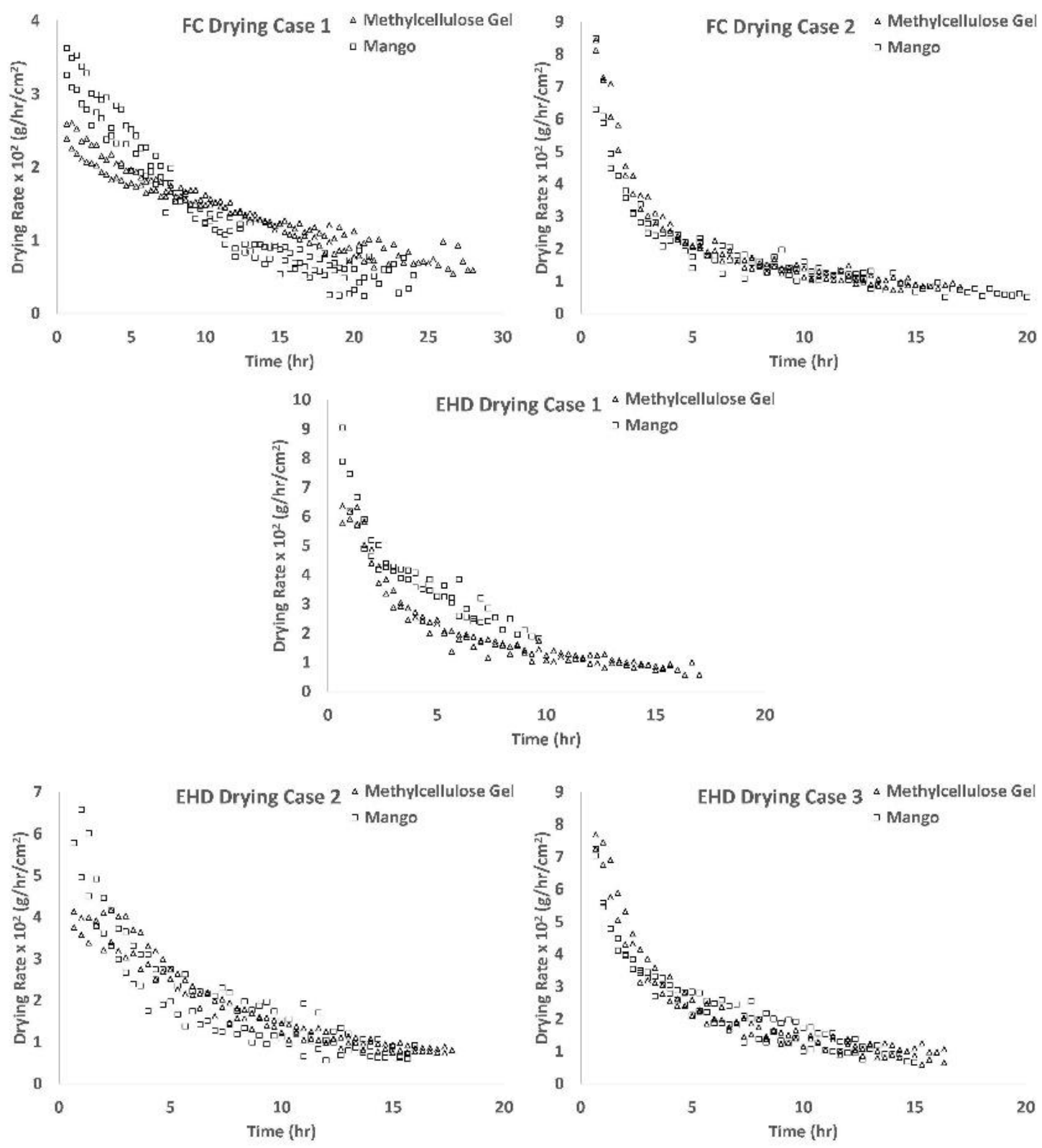

Fig 1 Drying rate (normalized to initial surface area of test specimen, $\mathrm{cm}^{2}$ ) over time of methylcellulose gel verses mango for all FC and EDH drying experimental cases. 

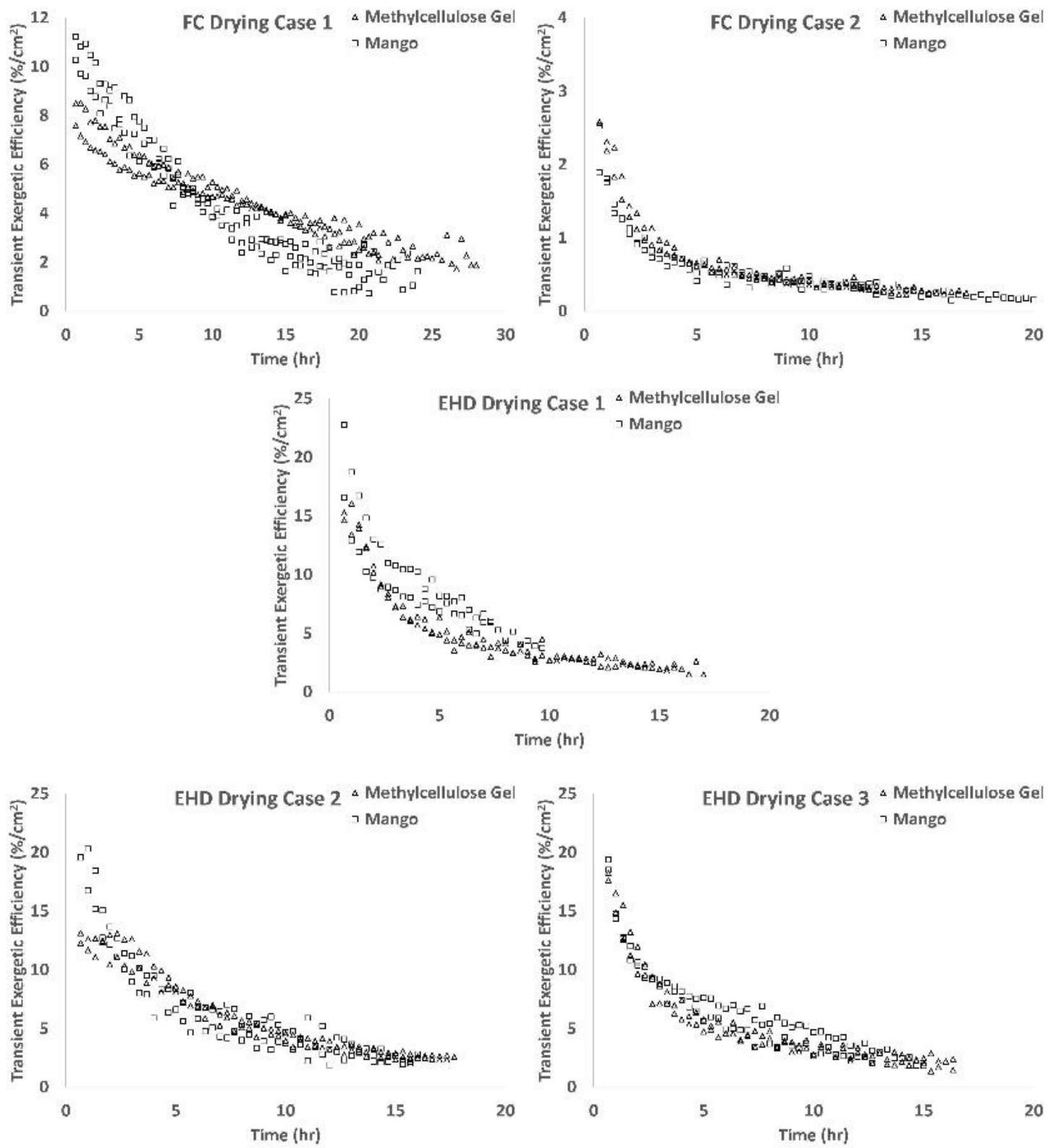

Fig 2 Transient Exergetic Efficiency (normalized to initial surface area of test specimen, $\mathrm{cm}^{2}$ ) over time of methylcellulose gel verses mango for all FC and EDH drying experimental cases. 
ASME Journal of Heat Transfer

Table 1 Placement of wire-electrode for EHD drying experiments.

\begin{tabular}{|l|l|l|l|l|l|l|}
\hline $\begin{array}{l}\text { Type of } \\
\text { Drying }\end{array}$ & Case & $\begin{array}{l}\text { Airflow } \\
\text { Velocity } \\
(\mathrm{m} / \mathrm{s})\end{array}$ & $\begin{array}{l}\text { Electrode alignment } \\
\text { relative to airflow } \\
\text { direction }\end{array}$ & $\begin{array}{l}\text { Number of } \\
\text { electrodes }\end{array}$ & $\begin{array}{l}\text { Distance between } \\
\text { electrode } \\
\text { and drying surface }(\mathrm{cm})\end{array}$ & $\begin{array}{l}\text { Applied } \\
\text { voltage } \\
(\mathrm{kV})\end{array}$ \\
\hline \multirow{2}{*}{$\begin{array}{l}\text { FC } \\
\text { drying }\end{array}$} & 1 & 0.3 & - & - & - & - \\
\hline \multirow{2}{*}{$\begin{array}{l}\text { EHD } \\
\text { drying }\end{array}$} & 2 & 3.0 & - & - & - & - \\
\cline { 2 - 7 } & 2 & 0.3 & Perpendicular & 1 & 7 & 22 \\
\cline { 2 - 7 } & 3 & 0.3 & Parallel & 1 & 4 & 10 \\
\hline
\end{tabular}


Table 2 Initial test specimen properties and the total drying time, the exergy supplied by EHD and air, as well as the exergy used for drying, and exergetic efficiency (normalized to initial surface area of test specimen, $\mathrm{cm}^{2}$ ) for each FC and EHD drying case for both the methylcellulose gel and mango (each value is shown as an average of the two experimental runs per case with standard deviation).

\begin{tabular}{|c|c|c|c|c|c|c|c|c|c|}
\hline \multirow[b]{2}{*}{$\begin{array}{l}\text { Type of } \\
\text { Drying }\end{array}$} & \multirow[b]{2}{*}{ Case } & \multicolumn{3}{|c|}{ Initial Test Specimen Properties } & \multicolumn{5}{|c|}{$*$ for when M.C. $=50 \%$} \\
\hline & & $\begin{array}{c}\text { Initial } \\
\text { Sample } \\
\text { Mass (g) }\end{array}$ & $\begin{array}{l}\text { Initial } \\
\text { area of } \\
\text { Sample } \\
\left(\mathrm{cm}^{2}\right)\end{array}$ & $\begin{array}{c}\text { Initial } \\
\text { Moisture } \\
\text { Content } \\
\text { (M.C.) }\end{array}$ & $\begin{array}{c}* \text { Drying } \\
\text { Time (hr) }\end{array}$ & $\begin{array}{c}\text { Exergy } \\
\text { Supplied } \\
\text { by Air } \\
\text { (kJ) }\end{array}$ & $\begin{array}{c}\text { Exergy } \\
\text { Supplied } \\
\text { by EHD } \\
(\mathrm{kJ})\end{array}$ & $\begin{array}{l}\text { *Exergy } \\
\text { Used per } \\
\text { unit area } \\
\left(\mathrm{kJ} / \mathrm{cm}^{2}\right)\end{array}$ & $\begin{array}{c}* \text { Exergetic } \\
\text { Efficiency } \\
\text { per unit } \\
\text { area } \\
\left(\% / \mathrm{cm}^{2}\right) \\
\end{array}$ \\
\hline \multirow[t]{4}{*}{$\begin{array}{l}\text { FC } \\
\text { Drying }\end{array}$} & 1: M. gel & $\begin{array}{l}119.43 \pm \\
9.60\end{array}$ & $\begin{array}{l}225.00 \pm \\
0.00\end{array}$ & $\begin{array}{l}0.83 \pm \\
0.00\end{array}$ & $\begin{array}{l}24.83 \pm \\
4.95\end{array}$ & $\begin{array}{l}318.25 \pm \\
70.46\end{array}$ & - & $\begin{array}{l}14.44 \pm \\
1.13\end{array}$ & $\begin{array}{l}4.61 \pm \\
0.67\end{array}$ \\
\hline & 1: Mango & $\begin{array}{l}46.75 \pm \\
2.67\end{array}$ & $\begin{array}{l}104.38 \pm \\
7.42\end{array}$ & $\begin{array}{l}0.86 \pm \\
0.04\end{array}$ & $\begin{array}{l}22.33 \pm \\
2.36\end{array}$ & $\begin{array}{l}293.87 \pm \\
27.95\end{array}$ & - & $\begin{array}{l}13.22 \pm \\
0.15\end{array}$ & $\begin{array}{l}4.52 \pm \\
0.38\end{array}$ \\
\hline & 2: M. gel & $\begin{array}{l}124.63 \pm \\
2.52\end{array}$ & $\begin{array}{l}225.00 \pm \\
0.00\end{array}$ & $\begin{array}{l}0.83 \pm \\
0.00\end{array}$ & $\begin{array}{l}16.00 \pm \\
1.41\end{array}$ & $\begin{array}{l}2141.28 \pm \\
250.07\end{array}$ & - & $\begin{array}{l}15.03 \pm \\
0.26\end{array}$ & $\begin{array}{l}0.71 \pm \\
0.07\end{array}$ \\
\hline & 2: Mango & $\begin{array}{l}49.00 \pm \\
0.17\end{array}$ & $\begin{array}{l}100.27 \pm \\
6.46\end{array}$ & $\begin{array}{l}0.84 \pm \\
0.04 \\
\end{array}$ & $\begin{array}{l}16.50 \pm \\
4.95\end{array}$ & $\begin{array}{l}2273.19 \pm \\
697.28\end{array}$ & - & $\begin{array}{l}14.09 \pm \\
1.39 \\
\end{array}$ & $\begin{array}{l}0.64 \pm \\
0.14 \\
\end{array}$ \\
\hline \multirow[t]{6}{*}{$\begin{array}{l}\text { EHD } \\
\text { Drying }\end{array}$} & 1: M. gel & $\begin{array}{l}120.34 \pm \\
6.15\end{array}$ & $\begin{array}{l}225.00 \pm \\
0.00\end{array}$ & $\begin{array}{l}0.83 \pm \\
0.00\end{array}$ & $\begin{array}{l}16.33 \pm \\
0.94\end{array}$ & $\begin{array}{l}238.39 \pm \\
17.58\end{array}$ & $\begin{array}{l}4.84 \pm \\
0.43\end{array}$ & $\begin{array}{l}14.48 \pm \\
0.65\end{array}$ & $\begin{array}{l}5.11 \pm \\
0.08\end{array}$ \\
\hline & 1: Mango & $\begin{array}{l}51.62 \pm \\
1.73\end{array}$ & $\begin{array}{l}111.76 \pm \\
4.04\end{array}$ & $\begin{array}{l}0.83 \pm \\
0.01\end{array}$ & $\begin{array}{l}8.50 \pm \\
1.65\end{array}$ & $\begin{array}{l}138.94 \pm \\
46.73\end{array}$ & $\begin{array}{l}16.12 \pm \\
2.75\end{array}$ & $\begin{array}{l}14.57 \pm \\
0.97\end{array}$ & $\begin{array}{l}9.80 \pm \\
2.50\end{array}$ \\
\hline & 2: M. gel & $\begin{array}{l}116.44 \pm \\
10.80\end{array}$ & $\begin{array}{l}225.00 \pm \\
0.00\end{array}$ & $\begin{array}{l}0.83 \pm \\
0.00\end{array}$ & $\begin{array}{l}17.50 \pm \\
0.24\end{array}$ & $\begin{array}{l}223.39 \pm \\
1.45\end{array}$ & $\begin{array}{l}2.92 \pm \\
0.73\end{array}$ & $\begin{array}{l}14.08 \pm \\
1.28\end{array}$ & $\begin{array}{l}6.22 \pm \\
0.51\end{array}$ \\
\hline & 2: Mango & $\begin{array}{l}43.72 \pm \\
4.68\end{array}$ & $\begin{array}{l}98.89 \pm \\
0.13\end{array}$ & $\begin{array}{l}0.86 \pm \\
0.02\end{array}$ & $\begin{array}{l}15.83 \pm \\
0.24\end{array}$ & $\begin{array}{l}201.00 \pm \\
16.05\end{array}$ & $\begin{array}{l}1.22 \pm \\
0.09\end{array}$ & $\begin{array}{l}13.39 \pm \\
2.22\end{array}$ & $\begin{array}{l}6.60 \pm \\
0.57\end{array}$ \\
\hline & 3: M. gel & $\begin{array}{l}131.31 \pm \\
8.13\end{array}$ & $\begin{array}{l}225.00 \pm \\
0.00\end{array}$ & $\begin{array}{l}0.83 \pm \\
0.00\end{array}$ & $\begin{array}{l}16.33 \pm \\
0.00\end{array}$ & $\begin{array}{l}215.47 \pm \\
2.82\end{array}$ & $\begin{array}{l}70.95 \pm \\
5.24\end{array}$ & $\begin{array}{l}15.85 \pm \\
0.97\end{array}$ & $\begin{array}{l}5.53 \pm \\
0.39 \\
\end{array}$ \\
\hline & 3: Mango & $\begin{array}{l}58.35 \pm \\
2.29\end{array}$ & $\begin{array}{l}117.09 \pm \\
3.70\end{array}$ & $\begin{array}{l}0.85 \pm \\
0.05\end{array}$ & $\begin{array}{l}13.83 \pm \\
1.65\end{array}$ & $\begin{array}{l}187.03 \pm \\
19.61\end{array}$ & $\begin{array}{l}23.98 \pm \\
2.96\end{array}$ & $\begin{array}{l}14.31 \pm \\
2.13\end{array}$ & $\begin{array}{l}6.77 \pm \\
0.28\end{array}$ \\
\hline
\end{tabular}

